\title{
The Impact of Independent Directors on the Cash Conversion Cycle of American Manufacturing Firms
}

\author{
Amarjit Gill ${ }^{1}$, Nahum Biger ${ }^{2} \&$ John Obradovich ${ }^{3}$ \\ ${ }^{1}$ The University of Saskatchewan, Edwards School of Business, Department of Finance and Management \\ Science, Canada \\ ${ }^{2}$ School of Business, Carmel Academic Center, Haifa, Israel and TongJi university, Shanghai, China \\ ${ }^{3}$ Spring Arbor University, USA \\ Correspondence: Amarjit Gill, The University of Saskatchewan, Edwards School of Business, Department of \\ Finance and Management Science, 25 Campus Drive, Saskatoon, SK, S7N-5A7, Canada. Tel: 1-306-966-2547. \\ E-mail: gill@edwards.usask.ca
}

Received: August 8, 2014

Accepted: August 22, 2014

Online Published: December 25, 2014

doi:10.5539/ijef.v7n1p878

URL: http://dx.doi.org/10.5539/ijef.v7n1p87

\begin{abstract}
This study examined the impact of independent directors on the cash conversion cycle of American manufacturing firms. A sample of 189 American manufacturing firms listed on the New York Stock Exchange (NYSE) for a period of five years (from 2009-2013) was used. The findings indicate that the presence of independent directors on the board of directors shortens the inventory period and cash conversion cycle of manufacturing firms. The study contributes to the literature on the factors that shorten the cash conversion cycle of the firm. The results may be used by financial managers and operations managers.
\end{abstract}

Keywords: corporate governance, independent directors, board size, CEO duality, CEO tenure, audit committee, cash conversion cycle

\section{Introduction}

A rapid cash conversion cycle is necessary for the survival and prosperity of the firm. The components of the cash conversion cycle include accounts receivable (AR) days, accounts payable (AP) days, and inventory days (Gill \& Biger, 2013). Reduction in the cash conversion cycle days plays an important role in strengthening corporate solvency by improving operating cash flows; or the ability of the firm to meet short-term as well as long-term financial obligations. The key decisions by the board of directors that affect corporate solvency include, but are not limited to AR, AP and inventory (John \& Senbet, 1998).

Arguably, internal mechanisms of corporate governance are not performing their jobs well (see Jensen, 1989, 1993; John \& Senbet, 1998). This was evident by the financial scandals (e.g., Livent Inc., Corel Corporation, and Nortel, etc.) around the world and by the collapse of major organizations in the USA (e.g., Enron, World Com, Commerce Bank, and XL Holidays). These scandals have shaken the faith of investors in capital markets, as well as, the efficacy of existing corporate governance practices in promoting transparency and accountability (Gill \& Obradovich, 2012). Increasingly, American corporations are expanding in the domestic, as well as, the global market where they need independent directors to serve on the board in order to improve survivability and prosperity. Independent directors are outsiders who are not the shareholders of the firm. They serve as members of the board of directors and are involved in decision-making.

One of the main causes of financial distress and, consequently, bankruptcy is corporate insolvency, which arises from a firm's poor cash inflows. A long cash conversion cycle is among the most important factors that cause poor cash inflows. The board of directors is responsible for formulating policies regarding AR, inventory purchases and maintenance, accounts payable, and all other policies in the organization. Thus, board composition and CEO duality play an important role in the organization.

Poor policies regarding accounts receivable, accounts payable, and inventory management have a negative impact on the cash conversion cycle (Gill \& Biger, 2013). Because shareholders do not control independent directors, they are expected to play a positive role in shortening the cash conversion cycle by performing a stewardship role (i.e., advising the board of directors to make sound policies) in the organization. Independent 
directors have better knowledge about certain geographic locations; therefore, independent directors should play an important role in shortening the short cash conversion cycle. These broad considerations lead to the following research questions:

Does the presence of independent directors on the board of directors shorten the accounts receivable collection period?

Does the presence of independent directors on the board of directors shorten the inventory-holding period?

Does the presence of independent directors on the board of directors shorten the accounts payable period?

Does the presence of independent directors on the board of directors shorten the cash conversion cycle period?

Although, there have been studies on the role of independent directors in firm performance, no published studies were found on the relationship between the presence of independent directors on the board of directors, and the accounts receivable period, the inventory holding period, the accounts payable period, and the cash conversion cycle of the firm. This study fills the gap and contributes to the literature on the relationship between the presence of independent directors on the board of directors, and the accounts receivable period, the inventory holding period, the accounts payable period, and the cash conversion cycle by using a sample of American manufacturing firms. The results of this study can be generalized to American manufacturing firms.

\section{Literature Review}

The structure of the corporate board and its impact on firm behavior has been a debated issue in the literature (Anderson \& Reeb, 2004). The concept of board structure relies on agency theory that focused on the function of the board (Jensen \& Meckling, 1976; Fama \& Jensen, 1983; Hillman \& Dalziel, 2003; Arosa, Iturralde, \& Maseda, 2010). The principal-agent problem takes place in corporations because managers, who are supposed to make decisions on behalf of the shareholders, may not always work in the favor of shareholders to maximize their wealth. Therefore, inclusion of independent directors in the board of directors is an effective instrument for monitoring the senior managers to cope with the agency problem and to reduce agency costs (Fama \& Jensen, 1983; Arosa, Iturralde, \& Maseda, 2010) in publicly traded firms. This is because independent directors have the ability to remain independent while overseeing operating matters, protect the assets of the firm, and hold the managers accountable to the firm's various key stakeholders to ensure the survival and success of the corporation (Gabrielsson \& Huse, 2005). The cash conversion cycle plays an important role in the survival and success of the firm. Although, independent directors are not directly responsible for maximizing shareholders' wealth, they are competent people who help managers enhance their decision-making processes by contributing their experiences. According to stewardship theory of Donaldson and Davis (1991), the main role of the board of directors is to advise and support management rather than to discipline and monitor as agency theory prescribes (Hillman \& Dalziel, 2003; Pieper et al., 2008).

It is common that independent directors (outsiders) are affiliated directors who are non-employee board members with existing or potential business ties to the firm (Daily, Johnson, Ellstrand, \& Dalton, 1998). From the agency theory point of view, affiliated directors seeking to protect or enhance their business relationship with the firm, are less objective and less effective monitors of the firm. Previous authors argued that affiliated directors often have conflicts of interests due to their current and expected future business relationship with the firm. This may impair their ability to monitor and discipline (see Baysinger \& Butler, 1985; Daily et al., 1998; Arosa, Iturralde, \& Maseda, 2010); therefore, independent directors are less effective in monitoring management actions and may not be effective in improving the cash conversion cycle of the firm. However, independent directors still are in a position to advise and support the board of directors, which assists in making sound working capital management and other important decisions that are useful in improving the financial health of the firm. Previous studies (Daily \& Dalton, 1994; Fich \& Slezak, 2008; Lajili \& Zéghal, 2010) found that the percentage of independent directors positively affect the financial health of the firm. Foo and Zain (2010) took a sample of 481 companies listed on the Malaysian Stock Exchange and found that more independent and diligent boards are associated with higher liquidity. This may be because the presence of the independent directors on the board of directors makes the cash conversion cycle period shorter.

CEO duality of leadership has become common in the corporations. CEO duality is one performing in the role of Chairman of the Board and CEO or, at least, is responsible for the duties usually associated with those positions. Gill and Biger (2013) collected data from American manufacturing firms and found that corporate governance improves accounts receivable management efficiency, accounts payable efficiency, and cash conversion cycle efficiency.

Jensen (1993) argued that a lack of independent leadership creates difficulty for boards to respond to failure in 
top management. According to Fama and Jensen (1983), concentration of decision management and control in one individual hinders boards' effectiveness in monitoring top management. However, when a CEO doubles as board chair, it affords the CEO the opportunity to carry out decisions without undue influence of bureaucratic structures (Kyereboah-Coleman, 2007, p. 9). Therefore, CEO duality can improve the efficiency of the cash conversion cycle; or, shorten the cash conversion cycle period. Table 1 show the findings of previous authors related to the relationship between corporate governance and the cash conversion cycle.

Table 1. Previous findings

\begin{tabular}{ll}
\hline Author & Findings \\
\hline Daily \& Dalton, 1994; Fich \& Slezak, & The percentage of independent directors positively impact on the financial \\
2008; Lajili \& Zéghal, 2010 & health of the firm. \\
Gill \& Biger (2013) & Corporate governance improves the accounts receivable management \\
& efficiency, accounts payable efficiency, and cash conversion cycle efficiency. \\
\hline
\end{tabular}

\subsection{Theoretical Foundation and Summary of Literature Review}

The first theoretical foundation of this study starts with agency theory of Jensen and Meckling (1976). According to agency theory, agency conflicts between principal and agent take place because managers may not work in the favor of the shareholders to maximize their wealth. Independent directors on the board of directors assist board members in formulating corporate policies that help monitoring managers to cope with the agency problem and to reduce agency cost; that is, monitoring accounts receivables, accounts payables, and inventory.

The second theoretical foundation of this study starts with the stewardship theory of Donaldson and Davis (1991). According to the stewardship theory, the motives of employees should align with the objectives of the corporation to pursue the interests of the shareholders. Independent directors, in the context of stewardship theory, play a role of stewards for the corporation to provide advice; help in aligning the interest of managers with the corporations; and support the board of directors in making important governance decisions to improve the prosperity and survivability of the firm. Thus, agency theory and stewardship theory serve as the theoretical foundation of this study. In summary, the limited availability of literature indicates that corporate governance influences the cash conversion cycle. Hence, it is hypothesized:

H1: The presence of independent directors on the board of directors shortens the accounts receivable collection period.

H2: The presence of independent directors on the board of directors shortens the inventory period.

H3: The presence of independent directors on the board of directors shortens the accounts payable period.

H4: The presence of independent directors on the board of directors shortens the cash conversion cycle period.

\section{Methods}

The study applied a co-relational and non-experimental research design. This process of measurement is central to quantitative research because it provides the fundamental connection between empirical observation and mathematical expression of quantitative relationships.

\subsection{Measurement}

To remain consistent with previous studies, measures pertaining to:

- Independent Directors were adopted from Platt and Platt (2012);

- Board Size, CEO Tenure, CEO Duality, Audit Committee, Cash Conversion Cycle, Sales Growth, Firm Performance, and Firm Size were adopted from Gill and Biger (2013).

Table 2 shows the measurements of the dependent, independent, and control variables that were used in regression analysis. 
Table 2. Proxy variables and their measurements

\begin{tabular}{ll}
\hline Dependent Variables & Measurement \\
\hline Accounts Receivable Collection Period $\left(\mathrm{AR}_{\mathrm{i}, \mathrm{t}}\right)$ & $(\mathrm{AR} / \mathrm{Sales}) \mathrm{x} 365$ days \\
Inventory Period $\left(\mathrm{INV}_{\mathrm{i}, \mathrm{t}}\right)$ & $(\mathrm{INV} /$ Cost of goods sold $) \times 365$ days \\
Accounts Payable Period $\left(\mathrm{AP}_{\mathrm{i}, \mathrm{t}}\right)$ & $(\mathrm{AP} / \mathrm{Cost}$ of goods sold $) \times 365$ days \\
Cash Conversion Cycle Period $\left(\mathrm{CCC}_{\mathrm{i}, \mathrm{t}}\right)$ & No. of days AR + No. of days INV - No. of days AP \\
Independent (explanatory) Variables & Measurement \\
Independent Directors $\left(\mathrm{ID}_{\mathrm{i}, \mathrm{t}}\right)$ & Number of independent directors serving on board \\
Board Size with Independent Directors $\left(\mathrm{BSWID}_{\mathrm{i}, \mathrm{t}}\right)$ & Number of directors including independent directors serving on board \\
Board Size without Independent Directors $\left(\mathrm{BSWOID}_{\mathrm{i}, \mathrm{t}}\right)$ & Number of directors without independent directors serving on board \\
CEO Duality $\left(\mathrm{CD}_{\mathrm{i}, \mathrm{t}}\right)$ & Assigned value 1 if same person occupied the post of the \\
& chairperson and the CEO and 0 for otherwise \\
CEO Tenure $\left(\mathrm{TN}_{\mathrm{i}, \mathrm{t}}\right)$ & Number of years serving as a CEO \\
Audit Committee $\left(\mathrm{AC}_{\mathrm{i}, \mathrm{t}}\right)$ & Number of audit committee members \\
Control Variables & Measurement \\
Firm Size $\left(\mathrm{FS}_{\mathrm{i}, \mathrm{t}}\right)$ & Natural logarithm of average assets \\
Sales Growth $\left(\mathrm{SG}_{\mathrm{i}, \mathrm{t}}\right)$ & $($ Current year sales - Previous year sales $) /$ Previous year sales \\
Firm Performance $\left(\mathrm{FP}_{\mathrm{i}, \mathrm{t}}\right)$ & Net income after tax / Revenue \\
\hline
\end{tabular}

Regression Models used in this study are as follows:

$$
\begin{gathered}
A R=\alpha+\beta_{1} B S W I D+\beta_{2} C D_{i t}+\beta_{3} T N_{i t}+\beta_{4} A C_{i t}+\beta_{5} F S_{i t}+\beta_{6} S G_{i t}+\beta_{7} F P_{i t}+\mu_{i t} \\
A R=\alpha+\beta_{1} B S W O I D+\beta_{2} C D_{i t}+\beta_{3} T N_{i t}+\beta_{4} A C_{i t}+\beta_{5} F S_{i t}+\beta_{6} S G_{i t}+\beta_{7} F P_{i t}+\mu_{i t} \\
I N V=\alpha+\beta_{1} B S W I D+\beta_{2} C D_{i t}+\beta_{3} T N_{i t}+\beta_{4} A C_{i t}+\beta_{5} F S_{i t}+\beta_{6} S G_{i t}+\beta_{7} F P_{i t}+\mu_{i t} \\
I N V=\alpha+\beta_{1} B S W O I D+\beta_{2} C D_{i t}+\beta_{3} T N_{i t}+\beta_{4} A C_{i t}+\beta_{5} F S_{i t}+\beta_{6} S G_{i t}+\beta_{7} F P_{i t}+\mu_{i t} \\
A P=\alpha+\beta_{1} B S W I D+\beta_{2} C D_{i t}+\beta_{3} T N_{i t}+\beta_{4} A C_{i t}+\beta_{5} F S_{i t}+\beta_{6} S G_{i t}+\beta_{7} F P_{i t}+\mu_{i t} \\
A P=\alpha+\beta_{1} B S W O I D+\beta_{2} C D_{i t}+\beta_{3} T N_{i t}+\beta_{4} A C_{i t}+\beta_{5} F S_{i t}+\beta_{6} S G_{i t}+\beta_{7} F P_{i t}+\mu_{i t} \\
C C C=\alpha+\beta_{1} B S W I D+\beta_{2} C D_{i t}+\beta_{3} T N_{i t}+\beta_{4} A C_{i t}+\beta_{5} F S_{i t}+\beta_{6} S G_{i t}+\beta_{7} F P_{i t}+\mu_{i t} \\
C C C=\alpha+\beta_{1} B S W O I D+\beta_{2} C D_{i t}+\beta_{3} T N_{i t}+\beta_{4} A C_{i t}+\beta_{5} F S_{i t}+\beta_{6} S G_{i t}+\beta_{7} F P_{i t}+\mu_{i t}
\end{gathered}
$$

Where

$\mu_{\mathrm{i}, \mathrm{t}}=$ The error term;

$\mathrm{i}, \mathrm{t}=$ Firm $\mathrm{i}$ in time $\mathrm{t}$.

- Regression models 1 and 2 compares impact of board size with the presence of independent directors on the board of directors (BSWID) and without the presence of independent directors on the board of directors (BSWOID) on the accounts receivable collection period.

- Regression models 3 and 4 compares impact of BSWID and BSWOID on the accounts inventory period.

- Regression models 5 and 6 compares impact of BSWID and BSWOID on the accounts payable period.

- Regression models 5 and 6 compares impact of BSWID and BSWOID on the cash conversion cycle period.

\subsection{Data Collection}

We built a database from a selection of approximately 700 financial reports of publicly traded companies between January 1, 2009 and December 31, 2013. The selection was drawn from Mergent Online [http://www.mergentonline.com/compsearch.asp] and Reuters [http://www.reuters.com/finance/stocks/] to form a random sample of manufacturing firms. Out of approximately 700 financial reports announced by public companies between January 1, 2009 and December 31, 2013, only 189 financial reports were usable. We used cross sectional yearly data. Since the random sampling method was used to select companies, the sample is considered representative. The sample included firms that manufacture and process products for the following sectors:

- Consumer products (39 firms);

- Services (2 firms);

- Utilities (7 firms), 
- Health care (3 firms),

- IT and communications (2 firms),

- Industrials (73 firms),

- Materials (59 firms), and

- Energy (4 firms).

\subsection{Descriptive Statistics}

Table 3 shows descriptive statistics of the collected variables. The explanation on descriptive statistics is as follows:

- Observations: 189 x $5=945$;

- $\mathrm{AR}=3.83$;

- INV = 4.17;

- $\mathrm{AR}=3.16$;

- $\mathrm{CCC}=4.50$;

- ID = 1.82;

- $\mathrm{BSWOID}=0.86$;

- $\mathrm{CD}=0.58$

- $\mathrm{TN}=2.32$

- $\mathrm{AC}=1.43$;

- $\mathrm{FS}=8.12$

- $\mathrm{SG}=0.03$;

- $\mathrm{FP}=0.24$

Table 3. Descriptive statistics of independent, dependent, and control variables (2009-2013)

\begin{tabular}{lllll}
\hline & Minimum & Maximum & Mean & Std. Deviation \\
\hline AR & 1.22 & 5.31 & 3.83 & 0.54 \\
INV & 1.89 & 5.63 & 4.17 & 0.57 \\
AP & 0.59 & 4.10 & 3.16 & 0.53 \\
CCC & 2.90 & 5.79 & 4.50 & 0.48 \\
ID & 0.00 & 2.48 & 1.82 & 0.53 \\
BSWID & 0.69 & 2.77 & 2.23 & 0.39 \\
BSWOID & 0.00 & 2.30 & 0.86 & 0.50 \\
CD & 0 & 1 & 0.58 & 0.49 \\
TN & 0.69 & 3.89 & 2.32 & 0.75 \\
AC & 0.69 & 2.30 & 1.43 & 0.31 \\
FS & 4.28 & 13.48 & 8.12 & 1.47 \\
SG & -0.74 & 0.69 & 0.03 & 0.15 \\
FP & 0.03 & 0.92 & 0.24 & 0.09 \\
\hline
\end{tabular}

Note. i) AR - Accounts receivable collection period; INV - Inventory holding period; AP - Accounts payable period; CCC - Cash conversion cycle period; ID - Number of independent directors serving on the board; BSWID - Board size with independent directors; BSWOID - Board size without independent directors; CD - CEO duality; TN - CEO tenure; AC - Number of audit committee members; FS Firm size; SG - Sales growth; FP - Firm performance.

ii) Natural logarithm was calculated for AR, INV, AP, CCC, ID, BSWID, BSWOID, TN, AC, and FS.

\subsection{Pearson Bivariate Correlation Analysis}

Table 4 shows that:

- AP is positively correlated with FS and negatively correlated with FP, and

- CCC is negatively correlated with BSWID. 
Table 4. Correlation analysis

\begin{tabular}{|c|c|c|c|c|c|c|c|c|c|c|c|c|}
\hline & $\mathrm{AR}$ & INV & AP & $\mathrm{CCC}$ & BSWID & BSWOID & $\mathrm{CD}$ & $\mathrm{TN}$ & $\mathrm{AC}$ & FS & SG & FP \\
\hline AR & 1 & & & & & & & & & & & \\
\hline INV & 0.09 & 1 & & & & & & & & & & \\
\hline $\mathrm{AP}$ & $0.52 * * *$ & 0.13 & 1 & & & & & & & & & \\
\hline $\mathrm{CCC}$ & $0.49 * * *$ & $0.79 * * *$ & 0.07 & 1 & & & & & & & & \\
\hline BSWID & -0.05 & -0.13 & 0.11 & $-.17 * *$ & 1 & & & & & & & \\
\hline BSWOID & 0.02 & -0.02 & 0.02 & -.04 & $0.27 * * *$ & 1 & & & & & & \\
\hline $\mathrm{CD}$ & 0.05 & -0.01 & 0.04 & .03 & 0.10 & 0.07 & 1 & & & & & \\
\hline $\mathrm{TN}$ & -0.05 & 0.07 & -0.09 & .14 & -0.10 & 0.08 & 0.07 & 1 & & & & \\
\hline $\mathrm{AC}$ & 0.11 & -0.05 & 0.14 & -.01 & 0.12 & 0.04 & $0.16^{* *}$ & -0.06 & 1 & & & \\
\hline FS & 0.06 & 0.01 & $0.28 * * *$ & -.01 & $0.38 * * *$ & 0.08 & $0.15^{* *}$ & -0.08 & $0.30 * * *$ & 1 & & \\
\hline SG & -0.03 & 0.01 & -0.10 & .04 & -0.09 & $-0.16^{* *}$ & -0.14 & -0.07 & 0.05 & -0.10 & 1 & \\
\hline $\mathrm{FP}$ & 0.02 & -0.02 & $-0.31 * * *$ & .14 & -0.03 & 0.06 & 0.12 & -0.01 & -0.11 & 0.02 & -0.01 & 1 \\
\hline
\end{tabular}

Note. $* \mathrm{p}<0.10, * * \mathrm{p}<0.05$, and $* * * \mathrm{p}<0.01$.

\section{Regression Analysis and Findings}

Section 4 presents the empirical findings on the relationship between the presence of independent directors and the cash conversion cycle of the American manufacturing firms. To minimize the issues of heteroskedasticity, we used the weighted least square (WLS) model with cross section weight of seven industries. We also calculated the common intercept for all variables and assigned a weight.

It is also important to understand that the omittance of certain variables and the variable measurement errors cause issues of endogeneity. To minimize the issues of endogeneity, we used the most important variables that affect the cash conversion cycle; borrowed measurements from the previous empirical studies; and used firms in data analysis that 'survived' during the study period only.

4.1 Corporate Governance with the Presence of Independent Directors on the Board of Directors and Accounts Receivables Period

The results reported in Table 5 below show that:

- AR is not associated with BSWID.

- When all the independent and control variables are included in the regression analysis, AR is not associated with any independent or control variable.

- AR is not associated with BSWOID.

- When all the corporate governance variables and control variables are included in the regression analysis, $\mathrm{AR}$ is not associated with any independent or control variables.

4.2 Corporate Governance with the Presence of Independent Directors on the Board of Directors and Inventory Period

The results reported in Table 5 below show that:

- INV is negatively associated with BSWID.

- When all the independent and control variables are included in the regression analysis, INV is not associated with any independent or control variable.

- INV is not associated with BSWOID.

- When all the corporate governance variables and control variables are included in the regression analysis, INV is not associated with any independent or control variables. 
Table 5. Regression results (dependent variables - accounts receivable period and inventory period)

\begin{tabular}{|c|c|c|c|c|c|c|c|c|}
\hline Dep Var & AR1 & AR2 & AR3 & AR4 & INV1 & INV2 & INV3 & INV4 \\
\hline \multirow[t]{2}{*}{ BSWID } & -0.06 & -0.08 & & & $-0.22 * *$ & -0.24 & & \\
\hline & $(-0.83)$ & $(-0.96)$ & & & $(-2.22)$ & $(-2.18)$ & & \\
\hline \multirow[t]{2}{*}{ BSWOID } & & & -0.05 & -0.06 & & & -0.04 & -0.07 \\
\hline & & & $(-0.79)$ & $(-0.83)$ & & & $(-0.50)$ & $(-0.88)$ \\
\hline \multirow[t]{2}{*}{$\mathrm{CD}$} & & 0.07 & & 0.07 & & 0.12 & & 0.11 \\
\hline & & (1.03) & & (1.03) & & (1.34) & & $(1.22)$ \\
\hline \multirow[t]{2}{*}{$\mathrm{TN}$} & & 0.04 & & 0.05 & & 0.02 & & 0.04 \\
\hline & & $(0.87)$ & & $(1.05)$ & & $(0.27)$ & & $(0.60)$ \\
\hline \multirow[t]{2}{*}{$\mathrm{AC}$} & & 0.06 & & 0.06 & & -0.14 & & -0.13 \\
\hline & & $(0.49)$ & & $(0.52)$ & & $(-0.97)$ & & $(-0.91)$ \\
\hline \multirow[t]{2}{*}{ FS } & & 0.02 & & 0.01 & & 0.01 & & -0.01 \\
\hline & & $(0.65)$ & & $(0.41)$ & & $(0.29)$ & & $(-0.35)$ \\
\hline \multirow[t]{2}{*}{ SG } & & 0.16 & & 0.14 & & 0.08 & & 0.06 \\
\hline & & $(0.72)$ & & $(0.60)$ & & $(0.27)$ & & $(0.19)$ \\
\hline \multirow[t]{2}{*}{ FP } & & -0.35 & & -0.31 & & 0.26 & & 0.36 \\
\hline & & $(-0.83)$ & & $(-0.74)$ & & $(0.50)$ & & $(0.69)$ \\
\hline \multirow[t]{2}{*}{ Constant } & $4.05 * * *$ & $3.82 * * *$ & $3.95 * * *$ & $3.70 * * *$ & $4.65^{* * *}$ & $4.65^{* * *}$ & $2.18 * * *$ & $4.28 * * *$ \\
\hline & $(22.54)$ & $(12.15)$ & $(61.62)$ & $(13.28)$ & $(20.31)$ & $(11.82)$ & $(50.66)$ & (12.14) \\
\hline Obs & 189 & 189 & 189 & 189 & 189 & 189 & 189 & 189 \\
\hline F Value & 0.69 & 0.69 & 0.62 & 0.66 & $4.92 * *$ & 1.22 & 0.26 & 0.63 \\
\hline $\mathrm{R}^{2}$ & 0.01 & 0.03 & 0.01 & 0.03 & 0.03 & 0.05 & 0.01 & 0.03 \\
\hline Adj $R^{2}$ & -0.01 & -0.01 & -0.01 & -0.01 & 0.02 & 0.08 & -0.01 & -0.01 \\
\hline
\end{tabular}

4.3 Corporate Governance with the Presence of Independent Directors on the Board of Directors and Accounts Payable Period

The results reported in Table 6 below show that:

- AP is positively associated with BSWID.

- When all the independent and control variables are included in the regression analysis, AP is positively associated with CD and FS, and negatively associated with FP.

- AP is not associated with BSWOID.

- When all the independent and control variables are included in the regression analysis, AP is positively associated with CD and FS, and negatively associated with FP.

4.4 Corporate Governance with the Presence of Independent Directors on the Board of Directors and Cash Conversion Cycle Period

The results reported in Table 6 show below that:

- CCC is negatively associated with BSWID.

- When all the independent and control variables are included in the regression analysis, CCC is negatively associated with BSWID and positively associated with TN.

- CCC is not associated with BSWOID.

- When all the independent and control variables are included in the regression analysis, CCC is negatively associated with BSWID and positively associated with TN. 
Table 6. Regression results (dependent variables - accounts payable period and cash conversion cycle period)

\begin{tabular}{|c|c|c|c|c|c|c|c|c|}
\hline Dep Var & AP1 & AP2 & AP3 & AP4 & $\mathrm{CCC} 1$ & $\mathrm{CCC} 2$ & $\mathrm{CCC} 3$ & $\mathrm{CCC} 4$ \\
\hline \multirow[t]{2}{*}{ BSWID } & $0.15^{*}$ & -0.03 & & & $-0.24 * * *$ & $-0.22 * *$ & & \\
\hline & $(1.75)$ & $(-0.39)$ & & & $(-2.88)$ & $(-2.51)$ & & \\
\hline \multirow[t]{2}{*}{ BSWOID } & & & 0.01 & -0.03 & & & -0.09 & $-0.12 *$ \\
\hline & & & $(0.03)$ & $(-0.43)$ & & & $(-1.36)$ & $(-1.82)$ \\
\hline \multirow[t]{2}{*}{$\mathrm{CD}$} & & $0.12 *$ & & $0.11^{*}$ & & 0.09 & & 0.09 \\
\hline & & (1.67) & & (1.68) & & $(1.28)$ & & $(1.23)$ \\
\hline \multirow[t]{2}{*}{$\mathrm{TN}$} & & -0.04 & & -0.03 & & $0.10 * *$ & & $0.12 * *$ \\
\hline & & $(-0.84)$ & & $(-0.76)$ & & $(2.17)$ & & $(2.60)$ \\
\hline \multirow[t]{2}{*}{$\mathrm{AC}$} & & -0.06 & & -0.05 & & -0.04 & & -0.03 \\
\hline & & $(-0.52)$ & & $(-0.50)$ & & $(-0.37)$ & & $(-0.29)$ \\
\hline \multirow[t]{2}{*}{ FS } & & $0.09 * * *$ & & $0.09 * * *$ & & 0.01 & & -0.01 \\
\hline & & $(3.47)$ & & $(3.52)$ & & $(0.41)$ & & $(-0.29)$ \\
\hline \multirow[t]{2}{*}{ SG } & & -0.01 & & -0.01 & & 0.21 & & 0.16 \\
\hline & & $(-0.01)$ & & $(-0.06)$ & & $(0.94)$ & & $(0.70)$ \\
\hline \multirow[t]{2}{*}{ FP } & & $-1.99 * * *$ & & $-1.98 * * *$ & & 0.61 & & $0.70 *$ \\
\hline & & $(-4.89)$ & & $(-4.86)$ & & $(1.46)$ & & (1.67) \\
\hline \multirow[t]{2}{*}{ Constant } & $2.88 * * *$ & $3.14 * * *$ & $3.21 * * *$ & $3.10 * * *$ & $5.03 * * *$ & $4.54 * * *$ & $4.58 * * *$ & $4.23 * * *$ \\
\hline & (14.62) & (10.30) & $(45.45)$ & (11.47) & $(26.96)$ & (14.55) & $(67.76)$ & (15.18) \\
\hline Obs & 189 & 189 & 189 & 189 & 189 & 189 & 189 & 189 \\
\hline F Value & $3.06^{*}$ & $5.90 * * *$ & 0.01 & $5.90 * * *$ & $8.27 * * *$ & $2.81 * * *$ & 1.84 & $2.36 * *$ \\
\hline $\mathrm{R}^{2}$ & 0.02 & 0.19 & 0.00 & 0.19 & 0.04 & 0.10 & 0.01 & 0.09 \\
\hline $\operatorname{Adj} R^{2}$ & 0.01 & 0.16 & -0.01 & 0.16 & 0.04 & 0.07 & 0.01 & 0.05 \\
\hline
\end{tabular}

Note. $* \mathrm{p}<0.10, * * \mathrm{p}<0.05$, and $* * * \mathrm{p}<0.01$.

\section{Discussion}

This study examined the impact of the presence of independent directors in the board of directors on the cash conversion cycle period of American manufacturing firms. The findings suggest that the presence of independent directors on the board of directors shortens the cash conversion cycle by shortening the inventory period. There is little difference in the impact of boards with independent directors and boards without independent directors. However, boards with independent directors have a stronger impact on the cash conversion cycle of American manufacturing firms. The presence of independent directors in the board of directors contributes in shortening the cash conversion cycle which favors American manufacturing firms because a shorter cash conversion cycle improves the efficiency of working capital management and consequently, the financial health the firm. Thus, this study lends some support to the findings of Daily and Dalton (1994); Fich and Slezak (2008); Lajili and Zéghal (2010); and Gill and Biger (2013) in that independent directors and corporate governance improve working capital management efficiency and the financial health of the firm.

The findings of this study also lend some support to the stewardship theory of Donaldson and Davis (1991) insofar as independent directors play a role of stewards for the corporations to provide advice, help in aligning the interest of managers with the corporations, and support the board of directors in making important governance decisions to improve the prosperity and survivability of the firm.

\section{Conclusion}

In conclusion, the presence of independent directors on the board of directors shortens the cash conversion cycle of American manufacturing firms by shortening inventory period. The shorter cash conversion cycle helps the firm in maximizing shareholder wealth. Thus, the presence of independent directors on the board of directors is beneficial for the American manufacturing firm.

The findings also show positive correlations between the cash conversion cycle, the accounts receivable collection period, and the inventory holding period; that, reduction in the accounts receivable period and the inventory holding period shorten the cash conversion cycle. Therefore, American manufacturing firms should consider:

- Reducing the accounts receivable collection period by offering cash discounts to speed up accounts receivable collection. 
- Following up on overdue accounts receivable accounts on a regular basis.

- Accepting electronic money (i.e., transfer of funds for accounts receivables electronically).

- Using five Cs of credit (i.e., character, capacity, collateral, conditions, and capital) before approving credit limits.

- Using lockboxes to speed up accounts receivable collections.

- Reducing the inventory period by increasing inventory turnover and by using inventory control methods and models, such as economic order quantity and just-in-time.

All of the above recommendations may help American manufacturing firms improve cash flow from operating activities. However, one should not forget about the practical implications of the study. The practical implication of this study is that the recommendations may not be applied to every American manufacturing firm because:

- The presence of independent directors on the board of directors may not shorten the accounts receivable period, inventory holding period, and consequently the cash conversion cycle period in every firm because of different geographic locations, different economic situations, and different internal corporate governance challenges, etc., can create barriers to success.

- Financial managers may not be able to implement changes in accounts receivables and inventory management policies due to reluctance from different departments such as marketing, finance, production, etc.

Based on the practical implications, the implementation of changes requires board of directors and senior financial managers to internalize the importance of showing genuine concern and respect for managers from other departments.

\section{Limitations}

The limitations of this study are as follows:

- The findings could only be generalized to firms similar to those that were included in this research; that is, American manufacturing firms.

- One should not ignore the practical implementation challenges of the findings. For example, the participation of independent directors on the board of directors may not be effective in every firm.

- One should not perceive that there is a causal relationship between the two variables; that is, the causal relationship between independent directors and cash conversion cycle.

\section{Future Research}

Other researcher may investigate the relationship between independent directors and cash conversion cycle by using samples of manufacturing firms from other countries to see if same relationships exist.

\section{References}

Anderson, C. R., \& Reeb, M. D. (2004). Board composition: Balancing family influence in S\&P 500 firms. Administrative Science Quarterly, 49(2), 209-237.

Arosa, B., Iturralde, T., \& Maseda, A. (2010). Outsiders on the board of directors and firm performance: Evidence from Spanish non-listed family firms. Journal of Family Business Strategy, 1(4), $236-245$. http://dx.doi.org/10.1016/j.jfbs.2010.10.004

Baysinger, B., \& Butler, H. (1985). Corporate governance and the board of directors: Performance effects of changes in board composition. Journal of Law, Economics, and Organizations, 1(1), 101-124.

Daily, C. M., \& Dalton, D. R. (1994). Corporate governance and the bankrupt firm: An empirical assessment. Strategic Management Journal, 15(8), 643-654. http://dx.doi.org/10.1002/smj.4250150806

Daily, C., Johnson, J., Ellstrand, A., \& Dalton, D. (1998). Compensation committee composition as a determinant of CEO compensation. Academy of Management Journal, 41(2), 209-220. http://dx.doi.org/10.2307/257103

Donaldson, L., \& Davis, J. H. (1993). The need for theoretical coherence and intellectual rigour in corporate governance research: Reply to critics of Donaldson and Davis. Australian Journal of Management, 18(2), 213-225. http://dx.doi.org/10.1177/031289629301800205

Fama, E. F., \& Jensen, M. C. (1983). Separation of ownership and control. Journal of Law and Economics, 26(2), 301-325. http://dx.doi.org/10.1086/467037 
Fich, E. M., \& Slezak, S. L. (2008). Can corporate governance save distressed firms from bankruptcy? An empirical analysis. Review of Quantitative Finance and Accounting, 30(2), 225-251. http://dx.doi.org/10.1007/s11156-007-0048-5

Foo, Y. B., \& Zain, M. M. (2010). Board independence, board diligence and liquidity in Malaysia. Journal of Contemporary Accounting and Economics, 6(2), 92-100. http://dx.doi.org/10.1016/j.jcae.2010.10.001

Gabrielsson, J., \& Huse, M. (2005). Outside directors in SME boards: A call for theoretical reflections. Corporate Board: Role, Duties and Composition, 1(1), 28-38.

Gill, A., \& Biger, N. (2013). The impact of corporate governance on working capital management efficiency of American manufacturing firms. Managerial Finance, 39(2), 116-132. http://dx.doi.org/10.1108/03074351311293981

Gill, A., \& Obradovich, J. (2012). The impact of corporate governance and financial leverage on the value of American firms. International Research Journal of Finance and Economics, 91, 46-51.

Hillman, A. J., \& Dalziel, T. (2003). Boards of directors and firm performance: integrating agency and resource dependence perspectives. Academy Management Review, 28(3), 383-396. http://dx.doi.org/10.2307/30040728

Jensen, M. (1989). Active investors, LBOs and the privatization of bankruptcy. Journal of Applied Corporate Finance, 2, 35-44. http://dx.doi.org/10.1111/j.1745-6622.1989.tb00551.x

Jensen, M. (1993). The modern industrial revolution, exit, and the failure of internal control systems. Journal of Finance, 48, 831-880. http://dx.doi.org/10.2307/2329018

Jensen, M. C., \& Meckling, W. (1976). Theory of the firm: Managerial behaviour, agency costs and ownership $\begin{array}{lllll}\text { structure. Journal of } & \text { Financial 305-360. }\end{array}$ http://dx.doi.org/10.1016/0304-405X(76)90026-X

John, K., \& Senbet, L. W. (1998). Corporate governance and board effectiveness. Journal of Finance and Banking, 22(4), 371-403. http://dx.doi.org/10.1016/S0378-4266(98)00005-3

Kyereboah-Coleman, A. (2007). Corporate governance and firm performance in Africa: A dynamic panel data analysis. A paper prepared for the "International Conference on Corporate Governance in Emerging Markets. $\quad$ Retrieved from http://www.ifc.org/ifcext/cgf.nsf/AttachmentsByTitle/PS2.3/\$FILE/Kyereboah-Coleman\%2B-\%2BCorpora te\%2BGovernance.pdf

Lajili, K., \& Zéghal, D. (2010). Corporate governance and bankruptcy filing decisions. Journal of General Management, 35(4), 3-26.

Pieper, T. M., Klein, S., \& Jaskiewicz, P. (2008). The impact of goal alignment on board existence and top management team composition: Evidence from family-influenced business. Journal of Small Business Management, 46(3), 372-394. http://dx.doi.org/10.1111/j.1540-627X.2008.00249.x

Platt, H., \& Platt, M. (2012). Corporate board attributes and bankruptcy. Journal of Business Research, 65(8), 1139-1143. http://dx.doi.org/10.1016/j.jbusres.2011.08.003

\section{Copyrights}

Copyright for this article is retained by the author(s), with first publication rights granted to the journal.

This is an open-access article distributed under the terms and conditions of the Creative Commons Attribution license (http://creativecommons.org/licenses/by/3.0/). 